\section{Too much free information?}

Stockholm

THE Soviet Union has denied using the international interlibrary loan system to obtain sensitive defence-related information from Sweden. A spokesperson of the official Soviet news agency APN pointed out last week that, if the Soviet Union did indeed require such information, it could acquire it by a "clearer and safer method", using satellite photographs. The Swedish defence staff has, however, launched a special inquiry into possible leaks through the interlibrary loan service.

International loans from Sweden are handled by Lund University Library, one of the two Swedish copyright deposit libraries that receive a copy of every work published in Sweden. (The other is the Royal Library in Stockholm.) The Soviet Union borrows between 750 and 1,300 works from Sweden each year, mostly in the humanities. So far, only a handful of "sensitive" items have been requested, all so far from "open" unclassified literature. To refuse to send such items would run counter to Sweden's policy of open access to information, and would require the special intervention of the government. This, according to Nils Palmborg, the Lund librarian in charge of the loan service, is hardly likely at the present moment.

According to Palmborg, Lund was first alerted to the possibility of the loan service being used for non-academic ends man naval library requested a copy of Marinnytt (Marine News). This is in fact readily available from all Swedish embassies and cultural institutes, and the main puzzle about the request was why the East German navy should bother to use the loan service when they could simply have picked up a copy in East Berlin. The Lund librarians duly forwarded the copy, but felt it worthwhile to inform the Swedish defence staff and to keep a watch for further puzzling requests.

In autumn 1984, they received a request from the Soviet Union for details of naval harbours in Norrland (North Sweden) and of a hydrographical survey of the same region. Later came a request about an area of central Skania (southern Sweden) where there are several military installations. According to Bertil Lagerwall, chief press spokesman of the defence staff, the material requested in the latter case included maps, photographs and also details of new building works in the area, all of which would be of considerable interest to anyone planning an airborne invasion.

According to Palmborg, the Lund library has worked out an arrangement with the defence staff about such requests. some three years ago, when an East Ger-

\section{Giotto now on target for Halley's comet}

The Giotto spaceprobe, the European Space Agency's contribution to the fleet of six craft aimed at Comet Halley, was successfully launched by an Ariane 1 launcher from Kourou in French Guiana last week. The three-stage launcher placed the satellite in a geostationary transfer orbit, from which an on-board motor injected the craft into a heliocentric trajectory aimed at an encounter with Halley on 13 March next year.

One important aim of the mission is to enter the coma of the comet and, using a four-colour camera, obtain images of the nucleus, possible only from within the coma. The best resolution hoped for is $\mathbf{5 0}$ metres. The composition of the coma itself will be sampled by neutral and ion mass spectrometers and dust detectors, while the electromagnetic environment will be probed by magnetometers and plasma analysers. The spacecraft is not expected to survive beyond its closest approach to the nucleus of less than $\mathbf{5 0 0}$ kilometres due to the effect of dust impacts - its relative speed is expected to be 68 kilometres per second.

These experiments will to some extent be complemented by those aboard the five other spacecraft that should encounter Halley at about the same time (see table). Giotto's instruments will be switched on in plasma analysers will be used to sample the solar wind at the time of the encounter of the International Comet Explorer with the comet Giacobini-Zinner on 11 September. Philip Campbell September or October. In particular, the

Lund will forward the material to the library filing the request (in the case of the Soviet Union, the Lenin Library in Moscow), and will then notify the defence staff of what has been sent. The rationale here seems to be that, since the defence staff is notified only after the material has been sent the arrangement does not compromise Sweden's commitment to the free flow of information. There does not seem to be any overt international agreement that requests for the transfer of information should be a matter of confidence between the parties concerned, and the Swedes presumably feel that, if the motive behind the request is innocent, the person or organization filing it would have no valid objection to a third party (in this case the defence staff) being informed.

For whatever reason, both Lund and the defence staff kept quiet for several months about the agreement, which was worked out last February. It was first revealed by the Sydsvenska Dagbladed two weeks ago and evoked considerable public comment and concern. According to defence spokesman Lagerwall, however, the Swedish government's commitment is clear: "We cannot and will not censor open literature", he declares. Vera Rich

\section{Hans-Otto Wüster}

THE European thermonuclear fusion project suffered a serious blow at the end of last month, with the unexpected death of Dr Hans-Otto Wüster, the director of the JET (Joint European Torus) project. Dr Wüster (58) was a West German theoretical physicist with a PhD from the University of Köln, where he worked for seven years at the Institute of Theoretical Physics. Thereafter, he spent successive spells

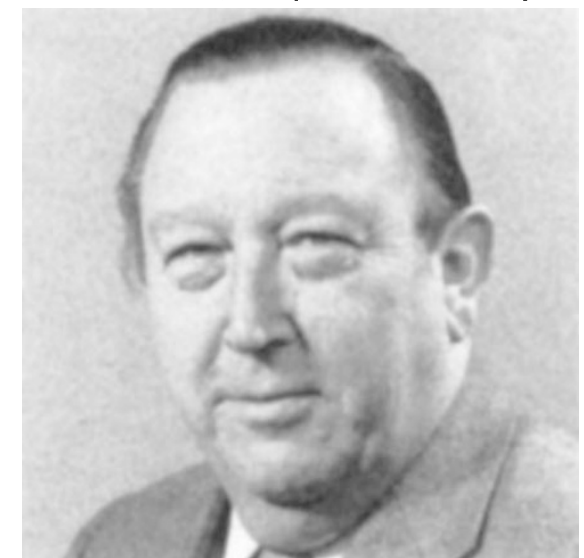
at the Deutches Elektronen-Synchrotron (DESY) at Hamburg and at CERN, Geneva, where he was deputy-director between 1971 and 1975 .

Dr Wüster was appointed director of JET in 1978. During his time, the torus was commissioned successfully. Much of Dr Wüster's contribution during his spell as director was to ensure political support for JET. But the laboratory says that he will also be much missed for his strong but sensitive style of management. 